\title{
THE PERCEPTIONS OF INDIGENOUS STUDENTS TOWARDS THE OCCIDENTAL EDUCATIONAL SYSTEM OF THE ENGLISH CLASS: A STUDY IN AN ECUADORIAN PUBLIC UNIVERSITY
}

\section{PERCEPCIONES DE ESTUDIANTES INDíGENAS HACIA EL SISTEMA EDUCATIVO OCCIDENTAL DE LA CLASE DE INGLÉS: UN ESTUDIO EN UNA UNIVERSIDAD PÚBLICA ECUATORIANA}

\section{Edgar Eduardo Heredia Arboleda ${ }^{1}$ \\ Verónica Patricia Egas Villafuerte ${ }^{2}$ \\ Ana Gabriela Reinoso Espinosa ${ }^{3}$ \\ Ángel Paul Obregon Mayorga ${ }^{4}$}

Escuela Superior Politécnica de Chimborazo, Riobamba, Ecuador.

Universidad Nacional de Chimborazo, Riobamba, Ecuador.

1 eheredia@unach.edu.ec 0967529110 https://scholar.google.com.ec/citations?user=1EEDkKsAAAAJ\&hl=es\&fbclid=Iw AR2Cinlhabjv7Hp-rRGDTYbQfUryitLD8gqMWk6H6tDYyFkFnGa42fbAbhM https://orcid.org/0000-0002-4099-9811

2 https://scholar.google.com/citations?user=kcVnJ5gAAAAJ\&hl=en\&fbclid=IwAR3DKT1Ebj_uPExCOGt-xvsSZ44mmFmFPKKoT7RLWEkEjJEru058WpYpbGQ https://orcid.org/0000-0003-1979-8924veronica.egas@unach.edu.ec 0968412704

3 https://scholar.google.com/citations?hl=es\&user=7_Lsav4AAAAJ\&view_op=list_works\&gmla=AJsN-F60hxY4yKRYfy2Ji9j0Owpflo--HvLpE-wWdN1Hvibq266zWOL_vNgFDGvmf44̄H4MK1PAvAwIJnEWnEv4GGoPW4B6zcHRttXVBwSNSbeOLNNbtp9 Nrl\&fbclid=IwAROSJkr8j0YI38CHONEXI6zkr9QdnLqypjg2TbZSPJ_ljpxaMoldCDQiLns

https://orcid.org/0000-0002-4518-9164 ana.reinoso@espoch.edu.ec 0995625303

4 https://scholar.google.com/citations?hl=es\&user=aDkq7tYAAAAJ\&view

op=list_works\&gmla=AJsN-F5-jSULyUyHSC3fvKIFqHkSS3kuYvGhU5U8yPA64MWIpPCUmy3ajliHZiA7-ns/3RYku5E2oMY3P8vgZ6MTJCnGLDRk6VgOdiWsNETk9VbBKadVjdg\&fbclid=IwAR3ulnskqulkKg_6GmTItCQJiM8bZN8ozVrZCBwP8zDrQbr OMiudJc19p-whttps://orcid.org/0000-0001-6831-4848 paul.obregon@espoch.edu.ec0 0995745427 


\section{ABSTRACT}

This investigation aimed to find out the way a group of Indigenous students perceives the occidental educational system of the English class. This Emic micro-ethnography was conducted with a sample of 30 participants, who are students of distinct English levels of a Public University located in the highlands of Ecuador. This sample was divided into two groups. Phenomenological interviews were carried out with the first group, in turn, its data were compared with that of the Questionnaire of the second group. The obtained results disclose that the lack of a real cognitive justice in the English class leads Indigenous students to feel as folklore producers, and not as Ecuadorian citizens who can teach different realities that contribute to the construction of an inclusive society. In general, this target group kindly demands in English classes not only a development of their national identity but also of their ethnic one.

KEYWORDS: Occidental Philosophy, Andean Philosophy, Acculturation, Cognitive Justice.

\section{RESUMEN}

Esta investigación tuvo como objetivo descubrir la forma en que un grupo de estudiantes indígenas percibe el sistema educativo occidental de la clase de inglés. Esta microetnografía de corte Emic se realizó con una muestra de 30 participantes, que son estudiantes de distintos niveles de inglés de una universidad pública ubicada en la Sierra de Ecuador. Esta muestra se dividió en dos grupos. Se realizaron entrevistas fenomenológicas con el primer grupo, a su vez, sus datos se compararon con los del Cuestionario del segundo grupo. Los resultados obtenidos revelan que la falta de una verdadera justicia cognitiva en la clase de inglés hace que los estudiantes indígenas se sientan como productores de folklore y no como ciudadanos ecuatorianos que pueden enseñar diferentes realidades que contribuyen a la construcción de una sociedad inclusiva. En general, este grupo objetivo amablemente exige en las clases de inglés no solo el desarrollo de su identidad nacional sino también de su identidad étnica.

PALABRAS CLAVE: Filosofía Occidental, FiLOSOFÍA ANDINA, ACULTURACIÓN, JUSTICIA COGNITIVA.

\section{INTRODUCTION}

Nowadays, the mastery of the Anglo-Saxon language is no longer perceived as a luxury of hegemonic groups, but as a definite need of the globalized world. Without a doubt, this phenomenon has touched every corner of the planet that today hundreds of people dominate this language. The indigenous communities have not been the exception; as a matter of fact, they are more interested in learning this language to let the outside world know about their philosophy (Haboud, 2009)

Unfortunately, Indigenous people face many inconveniences when learning a foreign language principally due to the cognitive injustice exerted by the globalization of the occidental philosophy. This dominant culture has obligated the indigenous population to eliminate their cultural background in the classroom and to adopt it as the only means of indoctrination. Sadly, this obligation has been detrimental to this population as it contributes to their acculturation. To counteract this problem, several inquiries conducted worldwide indicate the necessity of providing a legitimate cognitive justice through the adequate incorporation of ethnic literature in the educational curricula. In doing so, apprentices can gain more confidence in the learning process, preserve their culture, and reduce acculturation (Banks, 2017; Carrasquillo \& Rodríguez, 2007; De Sousa Santos 2015; Novikova, Gotovtseva, Lukina \& Sukhorukova, 2017; Sleeter, 2011). 
As highlighted above, cognitive justice regarding the reinforcement of ethnic identity should prevail in educational institutions, especially with language minority students. However, in some Ecuadorian universities, it is still ambiguous to speak of a real cognitive justice. On the one hand, indigenous students are expected to learn English based on their reality disregarding some Intercultural syllabi; nevertheless, the lack of it impairs their Andean pedagogy. An illustration of this Intercultural absence is the utilization of individualist occidental ethics in the assessment process and not a collective appraisal which is an essential part of Indigenous pedagogy. (Montaluisa, 1990 as cited by Martínez, 2009). As researchers, we are mindful that nobody speaks on behalf of others, but how many people out there have considered that the traits above, a fundamental part of Andean pedagogy, do not deal only with aboriginal language, dances, or vestment? How many of you know what characteristics of Andean philosophy are the most relevant to be incorporated in an Intercultural micro-curriculum?

These were the factors which intrigued the researchers to initiate this study with a group of Indigenous students who are currently facing difficulties in the Anglo-Saxon language. This inquiry aimed to delve deeper into their English learning complications in order to establish clear guidelines for the creation of an Intercultural micro-curriculum. For this, epistemologies of the south were employed in order to explore the most significant traits of their Andean pedagogy.

\section{METHODOLOGY AND PARTICIPANTS}

Researchers selected purposefully 30 adult indigenous participants: 16 females, and 14 males. This sample was divided into two groups. The first group consisted of 2 female native students of the Puruhá people -one was monolingual-. The second group was composed of 28 indigenous participants; 14 males and 14 females also belonging to the Puruhá people -20 were monolinguals-.

The perceptions of this sample were analyzed through a qualitative non-experimental investigation, with a transversal design of exploratory scope. This analysis also followed the ethnography of communication. Additionally, the instruments of data collection were as follows: three phenomenological interviews conducted by a single investigator for the first group, and one questionnaire carried out by two researchers for the second group.

The decision of phenomenological interviews was made to have the first group of participants reconstruct their previous and current learning experiences within the topic under study. They were also used to collect pertinent information about their attitudes and mood towards the English language learning. Also, these interviews contained the flexibility of open-ended questions.

The choice of the questionnaire was effectuated because of the facilities of its application, interpretation, and triangulation. This research instrument permitted decoding in detail the English language learning experiences of the second group of participants. It was also created using tools that report anonymous responses with demographic information followed by open and closed-ended questions regarding the topic under study.

This procedure took place in Riobamba, Ecuador in a public University with the corresponding consent of both authorities and indigenous students. In short, this study was chronologically divided into three phases as shown in Figure 1. 
Phase 1. - Application and Interpretation of the Interviews.

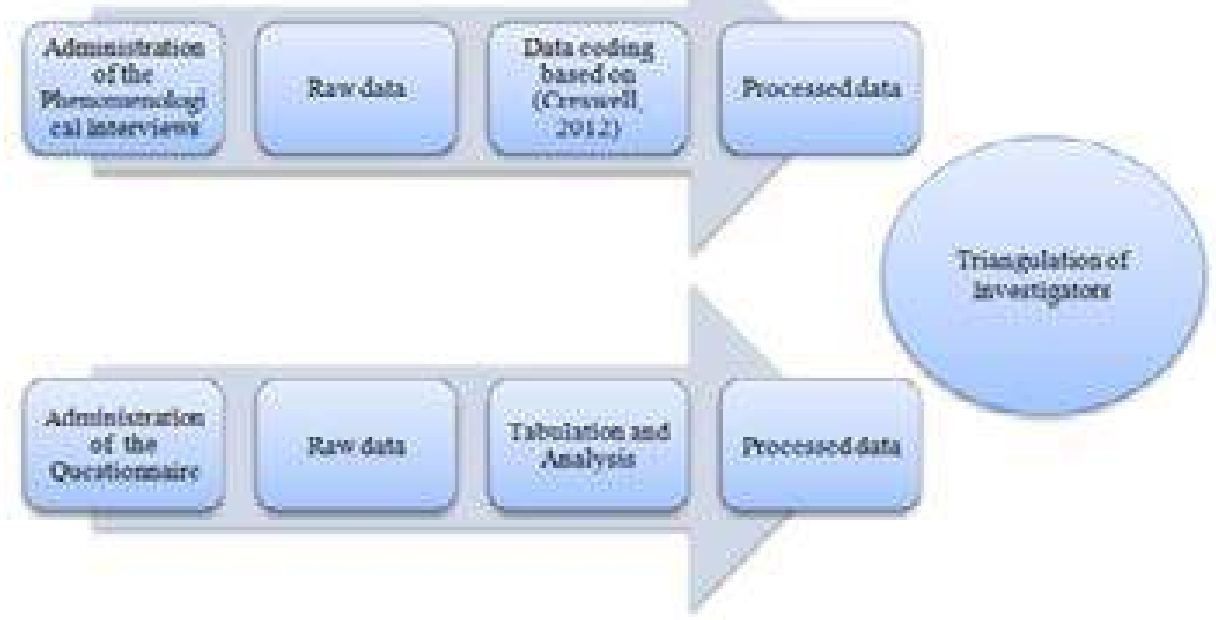

Figure 1. - Phases of the study

\section{RESULTS AND DISCUSSION}

According to the perceptions of indigenous students, what are the most significant traits of their Andean Pedagogy that should be rethought in the English class in order to design Intercultural syllabi? As stated in Figure 2, this research question was responded with the help of five relevant themes carefully generated from (Creswell, 2012) concerning the interviews conducted to the core group of two indigenous students and the questionnaire carried out to the second group of twenty-eight indigenous participants. Additionally, the generated themes clarified and revealed the starting points, which should be considered for the creation of the educational guidelines previously mentioned.

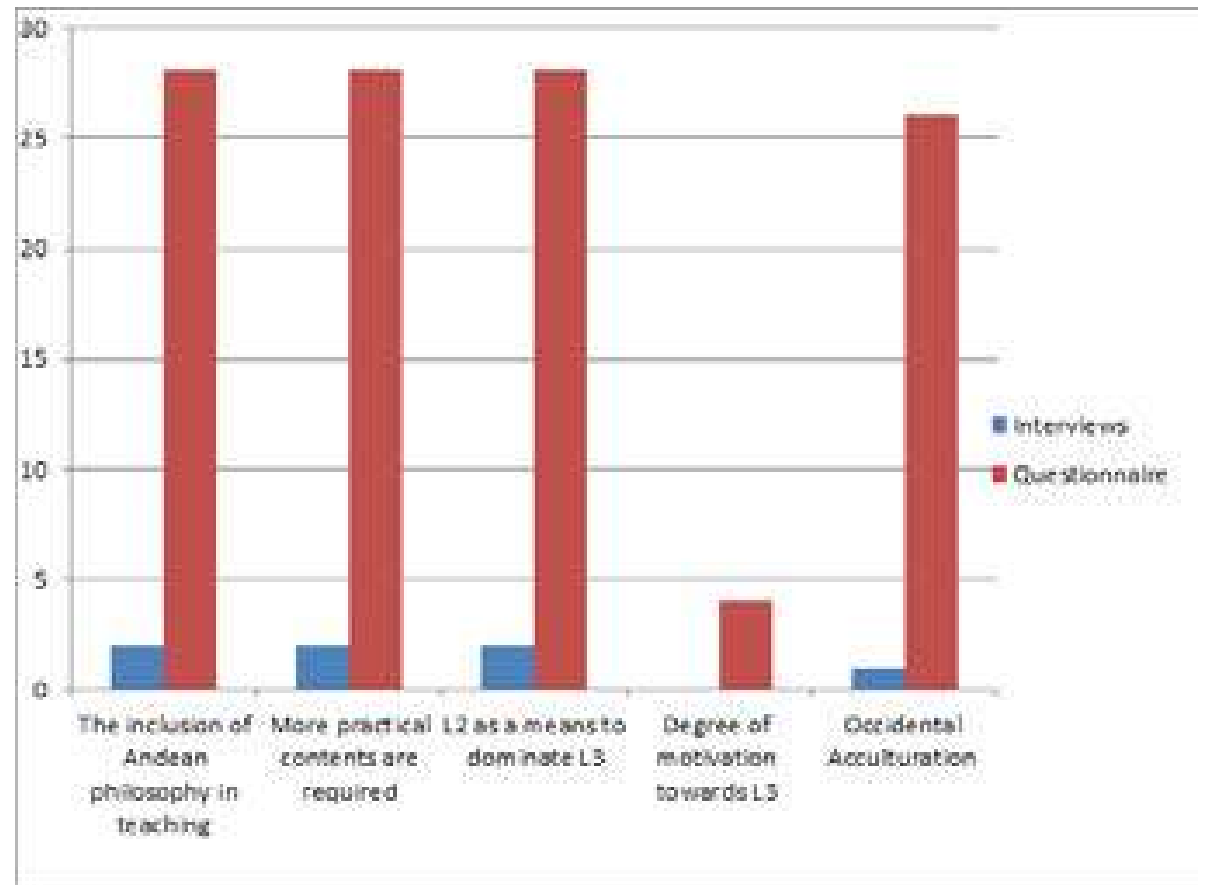

Figure 2. - Summary of triangulated data of both the Interviews and the Questionnaire. 


\subsection{THE INCLUSION OF ANDEAN PHILOS- OPHY IN TEACHING}

Condensed results from the three interviews demonstrated that the two participants consider that teachers must embrace the Andean philosophy. In the same way, results from the questionnaire showed that 28 participants agreed on the imperative necessity of including their Andean pedagogy in the English learning process. These findings indicate that their English learning experience has been precarious regarding Interculturality. In fact, the Interculturality, a fundamental part of educational transversal axes, paradoxically does not exist in Ecuador. In the absence of it, educators are ineffective with language minority students (Nieves, 2017; Sleeter, 2011; Walsh, 2009). In this regard, the thirty participants affirm that Andean wisdom must be considered as philosophy and not as a worldview, only this way their ethnic identity will be promoted. Hence, the findings imply that English teachers should be not only tolerant but also be curious about Andean pedagogy, once this happens, specific characteristics of Andean pedagogy can be extrapolated to the English class. Unquestionably, there are many traits of Andean pedagogy which might be contemplated in the classroom; however, new investigations should encounter the way to incorporate the wisdom of the council of elders in daily teaching practice; a topic little explored academically.

\subsection{MORE PRACTICAL CONTENTS ARE REQUIRED}

Results from the questionnaire indicated that twenty-eight participants feel they need more practical intercultural contents for learning English. Equally important, data collected from the interviews confirm that the two participants would like to work with more practice reflecting Interculturality. These findings show that their educational environment has been covered with theory and practice of the Occidental philosophy.
Speaking a foreign language represents not only an oral message but also the form of life, that is why, the instructional practice should focus on reinforcing among cultures the translation of their knowledge, values, beliefs, conceptions, etc. (De Sousa Santos, 2015; Estermann, 1998; Wittgenstein, 1953). In this light, the thirty indigenous students feel that their teaching and learning process is solely giving life to the theory and practice of the occidental culture, this, of course, fosters acculturation. These findings then imply the imperious necessity of intercultural polylog into their English classroom. For this, prospective research should develop mechanisms of Intercultural translation on Indigenous educational methodology.

\subsection{L2 AS A MEANS TO DOMINATE L3}

Because participants speak two languages L1 -Kichwa- and L2 -Spanish- it was necessary to identify the language used by them to acquire a third language L3 -English-. The applied questionnaires indicated that 28 students use their L2 to dominate L3. By corroborating this result, the interview also showed that $L 2$ is considered as a tool to produce L3. These findings display that regardless of the bilingualism of eleven participants, the thirty utilize L2 as a means to generate $L 3$ due to its linguistic similarities (Herdina and Jessner, 2002; Quinteros Baumgart \& Billick, 2017; Westergaard, Mitrofanova, Mykhaylyk \& Rodina, 2017). In respect thereof, the eleven bilingual indigenous students sustained that they do not rely on their L1 because its syntax, morphology, and phonology are complex and very different from other languages. However, the presence of their L1 appears unconsciously in the production of their $\mathrm{L} 2$, and L3. This antecedent, therefore, implies an urgent ecology of knowledge since this imperceptible phenomenon is a destroyer of their cultural identity. It would be prudent then to investigate this issue in depth from the psycholinguistics. 


\subsection{THE DEGREE OF MOTIVATION TO- WARDS L3}

In the questionnaire, it was found that only four students out of twenty-six were motivated to learn a third language L3; whereas the interview showed no results as the core group had no motivation at all, which constitutes a deficient percentage of motivation for learning English in the Andean culture. The findings exhibit that the teaching environment of twenty-six indigenous has not promoted the necessary intercultural conditions for learning to occur. On the contrary, the rest of the sample feels that their teaching environment is suitable. In the 21 st century, the role of motivation is transcendental in educational scenarios. In fact, it has been proven that despite technological tools with which people can learn, human brain learns better when another individual motivates, inspires, and acts as an example (Kuhl, Tsao \& Liu, 2003; Sigman, Peña, Goldin \& Ribeiro, 2014). In this context, the twenty-six indigenous students manifested that their English learning process is an anachronism which monitors their idiosyncrasy perniciously and punishes their Andean pedagogy. This situation implies necessarily the reinvention of teaching role regarding Interculturality. Accordingly, further research should focus on strategies to motivate indigenous apprentices based ON THEIR PEDAGOGY.

\subsection{OCCIDENTAL ACCULTURATION}

Results from the questionnaire indicate that twenty-six participants have adopted the Occidental culture setting aside their own. Moreover, in the interviews, only one participant from the core group has fallen into occidental acculturation. The findings show that twenty-six participants have not internalized the ethos of their nation-state; by contrast, only three participants are mindful of the cultural and sapiential richness of Ecuadorian cultures. In this connection, people experiencing acculturation are prone to feeling like strangers in their nations because their ethnic identity is directly or symbolically excluded from the educational, financial, social and political system. In the face of it, schooling is expected to utilize hegemonic instruments of the occidental culture to revitalize weak ones and to innovate the learning process of minoritized students with heterodox educational perspectives (Banks, 2017; Bourdieu, 1998; Carjuzaa, 2017; De Sousa Santos 2015; Paris, 2012). In this view, the twenty-six indigenous students sustained that their English language learning has been reductionist, and has not helped to perpetuate their culture, but rather to fragment it. This context implies an internal participatory curricular reform where aspects of indigenous students' language and culture are fully valued. In conclusion, further research should focus on finding heterodox teaching perspectives to fit them in the classroom according to indigenous students' needs.

\section{CONCLUSION}

This investigation discussed the learning complications of a group of indigenous students due to the imposition of the occidental philosophy in their English language learning. The findings have demonstrated that the English class in the majority of this target group has been following a reductionist occidental micro-curriculum. Unfortunately, this has only been strengthening indigenous students' national identity and not their ethnic one. In other words, their English class has been fostering acculturation. As stated by Banks (2017) people experiencing acculturation, in feeling social exclusion from a strong culture, they are more likely to set aside their idiosyncrasy in order to fit into that dominant culture. In the face of this background, as mentioned above, schooling must incorporate ethnic literature into its curricula to eradicate the phenomenon of acculturation. Although it is true that there is theoretical background underpinning the incorporation of ethnic literature into 
educational curricula, it is still uncertain what hits of minoritized students' philosophies should be taken into consideration to reinforce their cultural identity.

According to the perceptions of our target group, the starting point to promote their cultural identity which eventually can be reflected on an Intercultural curriculum is the reinterpretation of the word Interculturality. Unhappily, in the 21 st century, this word is understood as insidious tolerance which persists in seeing the Andean knowledge as a superstitious worldview and not as a legitimate philosophy which could imitate some features of the occidental thought. Lamentably, this assumption has impacted negatively on the motivation of indigenous students. For this reason, it is necessary to start recognizing the educational elements of their philosophy as a valid proposal for the occidental English microcurriculum; this entails heterodox educational perspectives where the pedagogy of indigenous students is highly valued.

After this, the use of occidental philosophy as the only means of English teaching solely indoctrinates this population. Therefore, the use of contents reflecting their cultural identity is indispensable for them to grasp the English Language. However, the use of these contents must exhibit a proper mastery of the Andean pedagogy, and not a precarious and folkloric discussion of their vestment, ancestral language or dances. Additionally, it is imperative to contemplate that the interference of their mother tongue is imperceptible and transferable either to their Spanish as well as to their English; in other words, the knowledge of their mother tongue delays the English learning process. (Guion, 2003) In this regard, indigenous students need special attention, adequate language environment, and appropriate assessment to overcome this difficulty which is a destroyer of their cultural identity.
With all this background, it is concluded that there is a definite urgency of integrating ecology of knowledge and Intercultural translation in the language learning environment of this population. But to attain this integration, it would be advisable to rethink the reductionist educational micro-curriculum with an Intercultural and challenging one that employs somehow the hints above which reflect the voice of the affected actors, and occidental educational instruments in order to convey not only a well-formulated Interculturality of tolerance but also an Interculturality of knowledge. Finally, we are still preoccupied with the emergencies and absences that we did not value in this investigation. However, we humbly hope we have not only contributed with guidelines for the creation of the Intercultural micro-curriculum mentioned above but also have established the path for future research.

\section{LIMITATIONS AND RECOMMENDATIONS}

Unfortunately, the phenomenon of acculturation made indigenous students hide their cultural identity; as a result, data collection was difficult to conduct. Establishing a good rapport with indigenous population is the key to obtain reliable findings, so that, if new researchers desire to apply quantitative or qualitative investigation, they must make sure beforehand they are involved in a long-term commitment before collecting data. It would then be advisable to carry out a similar study with longitudinal design to present findings that transversal design cannot provide in detail. 


\section{REFERENCIAS BIBLIOGRÁFICAS}

Banks, J. A. (2017). Failed Citizenship and Transformative Civic Education. Educational Researcher, 46 (7), 366-377. doi: $10.3102 / 0013189 \times 17726741$

Quinteros Baumgart, C. \& Billick, S. B. (2017). Positive Cognitive Effects of Bilingualism and Multilingualism on Cerebral Function: a Review. Psychiatric Quarterly, 1-11. doi:10.1007/s11126017-9532-9

Bourdieu, P. (1998). Practical reason: On the theory of action. Stanford, California: Stanford University Press.

Carjuzaa, J. (2017). Revitalizing Indigenous languages, cultures, and histories in Montana, across the United States and around the globe. Cogent Education, 4(1). doi:10.1080/233118 6x.2017.1371822

Carrasquillo, A., \& Rodríguez, V. (2002). Language minority students in the mainstream classroom. . Clevedon, England: Multilingual Matters.

Creswell, J. (2012). Analyzing and Interpreting Qualitative Data. Educational Research. Planning, Conducting and Evaluating Quantitative and Qualitative Research. (pp. 236-264). Pearson. Boston, MA.

De Sousa Santos, B. (2015). Epistemologies of the South: Justice against epistemicide. New York: Routledge.

Estermann, J. (1998). Filosofía andina: Estudio intercultural de la sabiduría autóctona andina. [Andean philosophy: Intercultural Study of Andean indigenous knowledge.] Quito, Ecuador: Ediciones Abya-Yala.

Guion, S. G. (2003). The Vowel Systems of Quichua-Spanish Bilinguals. Phonetica, 60(2), 98128. doi:10.1159/000071449
Haboud, M. (2009). Teaching foreign languages: A challenge to Ecuadorian bilingual intercultural education. International journal of English studies, 9(1). 63-80

Herdina, P., \& Jessner, U. (2002). A dynamic model of multilingualism: Perspectives of change in psycholinguistics. Clevedon: Multilingual Matters.

Kuhl, P. K., Tsao, F. M., \& Liu, H. M. (2003). Foreign-language experience in infancy: Effects of short-term exposure and social interaction on phonetic learning. Proceedings of the National Academy of Sciences, 100(15), 9096-9101. doi:10.1073/pnas. 1532872100

Martínez, C. (2009). La crisis del proyecto cultural del movimiento indígena. Repensando los movimientos indígenas. [The crisis of the cultural project of the indigenous movement. Rethinking indigenous movements] (pp. 173-196). Quito: FLACSO

Nieves, G. M. (2017). El Carácter Reconstructivo de la Justicia Indígena, en Chimborazo - Ecuador. El perdón y la justicia, desde los griegos hasta los pueblos indígenas de los andes. [Forgiveness and justice, from the Greeks to the indigenous peoples of the Andes] (pp. 123-158). Riobamba, Ecuador: Unidad de Publicaciones y de la Propiedad Intelectual (UPPI). Universidad Nacional de Chimborazo.

Novikova, Y. B., Gotovtseva, I. P., Lukina, A. A., \& Sukhorukova, D. V. (2017). Exploring language errors in culturally diverse classrooms. XLinguae, 10(4), 369-380. doi:10.18355/xl.2017.10.04.30

Paris, D. (2012). Culturally sustaining pedagogy: A needed change in stance, terminology, and practice. Educational Researcher, 41(3), 93-97. doi:10.3102/0013189x12441244 
Sigman, M., Peña, M., Goldin, A. P., \& Ribeiro, S. (2014). Neuroscience and education: prime time to build the bridge. Nature neuroscience, 17(4), 497-502. doi: $10.1038 / \mathrm{nn} .3672$

Sleeter, C. E. (2011). The academic and social values of ethnic studies: A research review. Washington, DC: National Education Association.

Walsh, C. (2009). Los disímiles proyectos políticos de mestizaje y de interculturalidad. Interculturalidad, Estado y Sociedad. [The dissimilar political projects of miscegenation and interculturality. Interculturality, State and Society.] (pp. 23-55). Quito, Ecuador: Abya Yala.

Westergaard, M., Mitrofanova, N., Mykhaylyk, R., \& Rodina, Y. (2017). Crosslinguistic influence in the acquisition of a third language: The Linguistic Proximity Model. International Journal of Bilingualism, 21(6), 666-682. doi:10.1177/1367006916648859

Wittgenstein, L. (1953) Philosophical Investigations, trans. G. E. M. Anscombe. Oxford: Basil Blackwell. 